\title{
Morphogenetic and tillering dynamics in Tanzania grass fertilized and non- fertilized with nitrogen according to season
}

\author{
Cláudio Fabrício da Cruz Roma ${ }^{1}$, Ulysses Cecato ${ }^{1}$, Cecílio Viega Soares Filho ${ }^{2}$, Geraldo \\ Tadeu dos Santos ${ }^{1}$, Ossival Lolato Ribeiro ${ }^{1}$, Bruno Shigueo Iwamoto ${ }^{1}$
}

\author{
1 Universidade Estadual de Maringá. \\ 2 Faculdade de Odontologia e Curso de Medicina Veterinária - UNESP/FOA - Campus de Araçatuba.
}

\begin{abstract}
The objectives of this study were to evaluate morphogenetic characteristics and tillering dynamics in Tanzania grass fertilized and non-fertilized with nitrogen, under intermittent grazing, in the spring and the summer. The main plots were composed of four nitrogen rates $(0,100,200$ and $300 \mathrm{~kg} / \mathrm{ha})$ and the subplots were growth seasons: spring (October, November and December) and summer (January, February and March). The experimental design was of randomized block with plots subdivided by time (seasons of the year) and four replications. Urea was used as nitrogen supply and was divided into two applications: one in the spring and another in the summer. The experimental units fertilized with $\mathrm{N}$ rates of 200 and $300 \mathrm{~kg} / \mathrm{ha}$ showed six cycles of pasture, with an average of 27 days of pasture interval, while the treatments with no fertilization and $100 \mathrm{~kg} / \mathrm{ha}$ of $\mathrm{N}$ showed only four and five cycles of pasture, respectively. Leaf elongation rate (LER) and the leaf appearance rate (LAR) increased linearly with increasing of $\mathrm{N}$ rates. The greatest population density occurred in summer with the higher nitrogen rates. The treatment without $\mathrm{N}$ fertilization showed the lowest growth of tiller population, while the other treatments exhibited growth rates above 50\% when compared with non-fertilized samples. Nitrogen rates significantly affect the leaf appearance rate and the leaf elongation rate, as well as the number of live leaves in plants of Tanzania grass in both spring and summer.
\end{abstract}

Key Words: intermittent grazing, leaf appearance rate, leaf elongation rate, Panicum maximum, senescence rate

\section{Introduction}

Increasing nitrogen $(\mathrm{N})$ supply in the soil is a way to enhance productivity rates of pastures, once $\mathrm{N}$ is a key element for morphogenesis and tiller formation of forage grasses (Pearse \& Wilman, 1984).

Morphogenesis is defined as the dynamics of formation and expansion of plants in space, described based on appearance of new organs (organogenesis), leaf elongation rate (growth), and senescence and leaf decomposition rates (Chapman \& Lemaire, 1993).

These morphogenetic variables are affected by the available levels of water, light, nitrogen and temperature. On the other hand, the structural variables are influenced by changes in morphogenetic responses and by frequency and intensity of grazing (Difante et al., 2008).

An increased number of tillers per plant implies in higher leaf areas and optimized soil coverage, thus contributing to a better tillering. Among the nutrients, nitrogen has proved to be the most effective at increasing the number of tillers, once its application on pastures has resulted in increased appearance and elongation of leaves, consequently yielding a higher production of both leaf and total matter (Cecato et al. 2001).

According to Bahmani et al. (2003), the stability index of tiller population might explain some variation in the number of tillers, inasmuch as values below 1.0 indicate that survival and the appearance of new tillers are insufficient to counterbalance the mortality rates, thereby favoring population to decline (Difante et al., 2008).

These structural modifications (leaf and stem proportion) result in maintenance of a dynamic growth in forage grasses and represent an adaptive strategy to grazing, which assures the productivity since the environmental resources, such as light, are properly exploited. Therefore, the goal of the present study was to evaluate the morphogenesis and the tillering dynamics of Tanzania grass (Panicum maximum Jacq.) during spring and summer.

\section{Material and Methods}

The experiment was carried out at $23^{\circ} 25^{\prime} \mathrm{S}$ and $51^{\circ} 57^{\prime} \mathrm{W}$, with a mean altitude of $550 \mathrm{~m}$ above the sea level. The predominant climate in the region is classified as mesothermal 
humid subtropical Cfa according to Köppen, with an annual mean temperature of $22^{\circ} \mathrm{C}$. The area is characterized by a hot summer season, low frequency of severe blizzards and a higher rainfall rate during the summer. The experimental period ranged from October 2007 to March 2008 and the weather data during this period were collected close to the experimental site (Figure 1).

The soil of the experimental area is classified as yellowred dystrophic latosoil (EMBRAPA, 1999). Soil samples were collected for chemical analyses at depths of $0-10$ and $10-20 \mathrm{~cm}$ of soil prior the experiment (Table 1).

The soil acidity was corrected in June using dolomitic lime to elevate the base-saturation up to $60 \%$, as proposed by Werner et al. (1996), and super simple phosphorus at $40 \mathrm{~kg} / \mathrm{ha}$ was applied in soil prior the experiment. Nitrogen (N) doses were partitioned in two applications: half applied in the spring (November 12th, 2007) and another half applied in the summer (January 24th, 2008), using urea as nitrogen source $(45 \%$ of $\mathrm{N})$. Along with the first $\mathrm{N}$ application, $60 \mathrm{~kg} / \mathrm{ha}$ of potassium chloride were added to the soil $\left(60 \%\right.$ of $\left.\mathrm{K}_{2} \mathrm{O}\right)$.

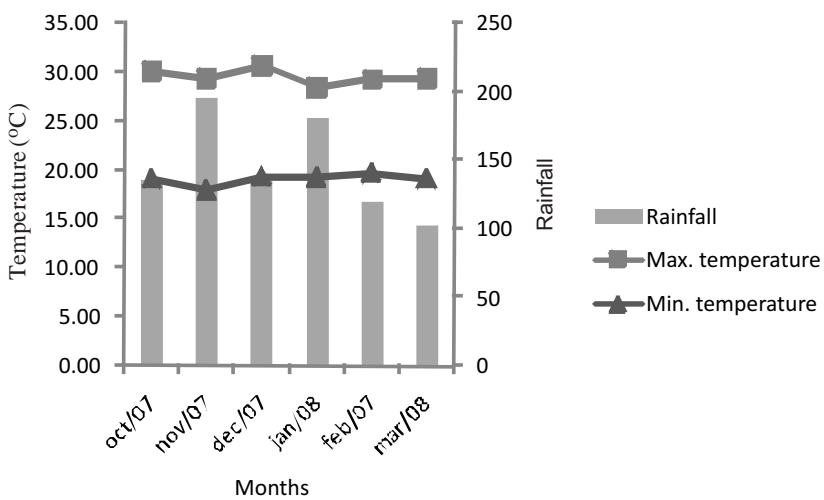

Source: Seed Laboratory from the Experimental Farm in Iguatemi (FEI).

Figure 1 - Rainfall and maximum and minimum temperatures from October 2007 to March 2008.
The experiment was established in a previously established pasture of Panicum maximum Jacq. cv. Tanzania for four years. This area had been already used for similar research studies and, therefore, the plants were well set. The experimental area encompassed $1,600 \mathrm{~m}^{2}$, divided into 16 lots with a mean area of $100 \mathrm{~m}^{2}$ in each experimental unit.

The four nitrogen doses (0, 100, 200 and $300 \mathrm{~kg} / \mathrm{ha}$ ) comprised the main plots and the subplots (growth seasons) were spring (October, November and December) and summer (January, February and March). A completely randomized experimental block design was established, with plots subdivided in time (season) using four repetitions .

Pasture management included intermittent grazing with variable stocking rate ( 2 to 3 animals per experimental unit) for a single day. The resting period varied according to the time required by plants to reach $70 \mathrm{~cm}$ in height within treatments, when dairy calves of nearly $300 \mathrm{~kg}$ each were allowed to graze up to reducing the pastures to a residual height of $30 \mathrm{~cm}$ above soil, on average. Each week, plant height was measured in the experimental units (performed at 15 representative points per paddock) up to reaching about $70 \mathrm{~cm}$ in height above the soil.

Ten representative tillers in pasture were tagged with a colored thread for morphogenetic evaluation: five within the tussock and five around the tussock, during pasture swarding. The tillers were tagged three days after the animal grazing. The length of the leaf blade and the height of ligule of the first expanded leaf were measured. Weekly, the length of leaf lamina, the number of green leaves, stem elongation rate and leaf senescence rate were measured in Tanzania grass. The measurements were carried out in paddocks until the grass reached $70 \mathrm{~cm}$ above soil, when the wire straws used to identify the tillers were removed, the leaf mass was evaluated and the animals were allowed to graze again to reduce the plants to $30 \mathrm{~cm}$ in height. These steps were successively repeated during the experimental period.

Table 1 - Chemical features of soil in Tanzania grass pastures at the beginning of the experimental period (March, 2007)

\begin{tabular}{|c|c|c|c|c|c|c|c|c|c|c|c|}
\hline \multirow{2}{*}{$\begin{array}{l}\mathrm{N} \text { dose } \\
\mathrm{kg} / \mathrm{ha}\end{array}$} & \multirow{2}{*}{$\begin{array}{l}\text { Depth } \\
\text { cm }\end{array}$} & \multirow{2}{*}{$\begin{array}{c}\mathrm{P}^{1} \\
\mathrm{mg} / \mathrm{dm}^{3}\end{array}$} & \multirow{2}{*}{$\begin{array}{c}\mathrm{C} \\
\mathrm{g} / \mathrm{dm}^{3}\end{array}$} & \multirow{2}{*}{$\begin{array}{c}\mathrm{pH} \\
\mathrm{CaCl}_{2}\end{array}$} & $\mathrm{H}+\mathrm{Al}$ & $\mathrm{Ca}^{2}$ & $\mathrm{Mg}^{2}$ & $\mathrm{~K}^{1}$ & SB & \multirow[t]{2}{*}{ CEC } & \multirow{2}{*}{$\begin{array}{l}\mathrm{V} \\
\%\end{array}$} \\
\hline & & & & & \multicolumn{5}{|c|}{$\mathrm{mmol} / \mathrm{dm}^{3}$} & & \\
\hline 0 & $0-10$ & 24.33 & 7.53 & 5.08 & 3.12 & 1.50 & 0.88 & 0.21 & 2.60 & 5.72 & 45.45 \\
\hline 0 & $10-20$ & 16.95 & 3.23 & 4.63 & 3.23 & 1.01 & 0.40 & 0.09 & 1.50 & 4.73 & 31.51 \\
\hline 100 & $0-10$ & 21.80 & 2.94 & 5.03 & 3.17 & 1.46 & 0.90 & 0.17 & 2.53 & 5.70 & 44.04 \\
\hline 100 & $10-20$ & 7.70 & 2.94 & 4.60 & 3.18 & 1.11 & 0.47 & 0.06 & 1.64 & 4.81 & 33.94 \\
\hline 200 & $0-10$ & 22.70 & 10.08 & 4.98 & 3.36 & 1.63 & 0.77 & 0.14 & 2.54 & 5.90 & 43.03 \\
\hline 200 & $10-20$ & 18.20 & 4.11 & 4.80 & 3.06 & 1.25 & 0.38 & 0.06 & 1.68 & 4.74 & 35.44 \\
\hline 300 & $0-10$ & 20.98 & 7.83 & 5.05 & 3.18 & 1.40 & 0.75 & 0.17 & 2.32 & 5.50 & 41.97 \\
\hline 300 & $10-20$ & 7.17 & 4.21 & 4.75 & 3.11 & 1.11 & 0.47 & 0.07 & 1.64 & 4.75 & 34.39 \\
\hline
\end{tabular}

SB - sum of bases; CEC - cation exchange capacity; V - Base-saturation percentage.

Twenty subsamples were collected per treatment to compose a sample.

${ }^{1}$ Extracted with Mehlich-1.

${ }^{2} \mathrm{Ca}$ and $\mathrm{Mg}$ - extracted with $\mathrm{KCl} 1 \mathrm{~mol} \mathrm{~L}^{-1}$. 
The following variables were used in the morphogenetic evaluation:

Leaf appearance rate: number of leaves (NGL) per tiller divided by the number of evaluation days - leaves/tiller/day; Phyllochron: time (in days) required for appearance of two consecutive leaves - days/leaf/tiller; Leaf elongation rate: sum of total elongation of leaf blade per tiller divided by the number of days during the evaluation period $\mathrm{cm} /$ tiller/day; Leaf life span (LLS): time spent between the appearance of a leaf up to its death, estimated according to the equation proposed by Lemaire \& Chapman (1996): LLS $=$ NGL $\times$ phyllochron (days); Number of green leaves: mean number of leaves under elongation and elongated leaves per tiller, disregarding the senescent leaves of each tiller; Final leaf length: mean length of all leaves present in the tiller measured from the leaf tip to the ligule $(\mathrm{cm})$.

Stem elongation rate: sum of total elongation of stems/ pseudostems per tiller divided by the number of days during the evaluation period - $\mathrm{cm} /$ tiller/day.

To evaluate the tillering, two tussocks were tagged per paddock comprising eight tussocks per treatment, totalizing 32 tagged tussocks. In the first evaluation, all tillers of each selected tussock were tagged with threads of a single color, identifying the reference tiller generation. Up to seven days after grazing in each paddock, a thread of a different color was used to identify the new tiller generation during regrowth in each measurement and tagging procedure.

Based on these measurements, the tiller population density per $\mathrm{m}^{2}$ was obtained. The calculation was performed as follows: $\mathrm{TAR}=$ new tillers/total of living tillers from previous tagging, divided by the number of cycle days and TMR = dead tillers/total of living tillers from previous tagging divided by the number of cycle days.

The stability index (P1/P0) in tiller population was calculated according to the method described by Bahmani et al. (2003) using the expression: P1/P0 = TSR (1+TAR), in which TSR (tiller survival rate) $=1-\mathrm{TMR}$, where P1/P0 = proportion between the tiller population in cycle 1 and the population from cycle 0 .

The data were tested for error normality and variance homogeneity; the statistical analyses were carried out using the GLM procedure available in SAS software (Statistical Analysis System, version 8.0) using the model of plots subdivided in time, with the $\mathrm{N}$ doses regarded as the main plots, and the seasons, as the subplots. Means were compared by F-test and SNK mean test at a significance level of 5\%. Regression analyses using $\mathrm{N}$ doses as a function were performed.

\section{Results and Discussion}

The number of cycles and grazing intervals during the experimental period was influenced by $\mathrm{N}$ doses.

The treatments with $0,100,200$ and $300 \mathrm{~kg} / \mathrm{ha}$ of $\mathrm{N}$ yielded, respectively, four grazing cycles with 41 days of interval on average ( 0 dose), five cycles with 35 days of grazing interval on average (using $100 \mathrm{~kg} / \mathrm{ha}$ ) and six cycles with a mean interval of 27 days (at 200 and $300 \mathrm{~kg} / \mathrm{ha}$ ). The treatment with the highest $\mathrm{N}$ concentrations during January and February (summer) presented 28 days of grazing interval (Tables 2 and 3). Similar results were reported by Barbosa et al. (2007) analyzing Tanzania grass when $200 \mathrm{~kg} / \mathrm{ha}$ of N were added combining intensity $\times$ frequency of grazing.

The speed of pasture recovery after grazing depends on variation of edaphoclimatic features. Fluctuations of weather and stress conditions modify the morphology and the development rate of forage grasses (Buxton \& Fales, 1994).

The low number of grazing cycles in pastures free from nitrogen fertilization (four cycles) was related to the long period of regrowth, which began during spring and extended up to the end of summer. In this season, up to 41-day grazing intervals were observed for the control treatment. According to Uebele (2002), pasture management based on fixed resting periods are inadequate, once it can lead to significant losses in forage quality and production.

In Napier grass (Pennisetum purpureum), Wendling et al. (2004) showed that resting periods of 24 days yielded lower production of dry leaf matter when compared with

Table 2 - Total number of grazing cycles during the experimental period using Tanzania grass fertilized and non-fertilized with nitrogen in each season

\begin{tabular}{ccc}
\hline $\begin{array}{c}\text { Treatments } \\
(\mathrm{kg} / \mathrm{ha} \text { of } \mathrm{N})\end{array}$ & $\begin{array}{c}\text { Number of } \\
\text { cycles in the spring }\end{array}$ & $\begin{array}{c}\text { Number of } \\
\text { cycles in the summer }\end{array}$ \\
\hline 0 & 2 & 2 \\
100 & 3 & 2 \\
200 & 3 & 3 \\
300 & 3 & 3 \\
\hline
\end{tabular}

Table 3 - Grazing interval (in days) during the experimental period using Tanzania grass fertilized and non-fertilized with nitrogen in each season

\begin{tabular}{ccc}
\hline $\begin{array}{c}\text { Treatments } \\
(\mathrm{kg} / \mathrm{ha} \text { of } \mathrm{N})\end{array}$ & $\begin{array}{c}\text { Grazing interval } \\
\text { in the spring (days) }\end{array}$ & $\begin{array}{c}\text { Grazing interval } \\
\text { in the summer (days) }\end{array}$ \\
\hline 0 & 40 & 42 \\
100 & 32 & 39 \\
200 & 27 & 28 \\
300 & 27 & 28 \\
\hline
\end{tabular}


30-day periods, but the leaf matter obtained within 24-day intervals presented higher nutrition values, leading to increased milk production, thus demonstrating that fixation of resting days in grass are not the best strategy to achieve higher productivity levels.

As the $\mathrm{N}$ doses increased, the leaf appearance rate presented linear rise (Figure 2); values ranged from 0.07 (no nitrogen fertilization) to 0.09 leaves/day (300 kg/ha of N), with an increasing of $28.5 \%$ when compared to the lack of $\mathrm{N}$ application. This value range is lower than that reported by Cavalcante et al. (2002), analyzing different cutting heights and similar fertilization over an experimental area with Brachiaria decumbens under grazing, whose values varied from 0.079 to 0.107 leaves/day.

As for the leaf elongation rate, the increased $\mathrm{N}$ doses promoted a linear growth of leaf elongation rate (Figure 2). Santos et. al. (2004), studying Mombaça grass (Panicum maximum cv. Mombaça) observed higher values of leaf elongation rate than those detected in the present research, reporting values of 1.82; 1.5; 6.58 and $9.51 \mathrm{~cm} /$ day.tiller in the fall, winter, spring and summer, respectively. This difference is due to genotype variation, once Mombaça grass presented a higher production of dry matter than Tanzania grass within the same period (Santos et al., 1999).
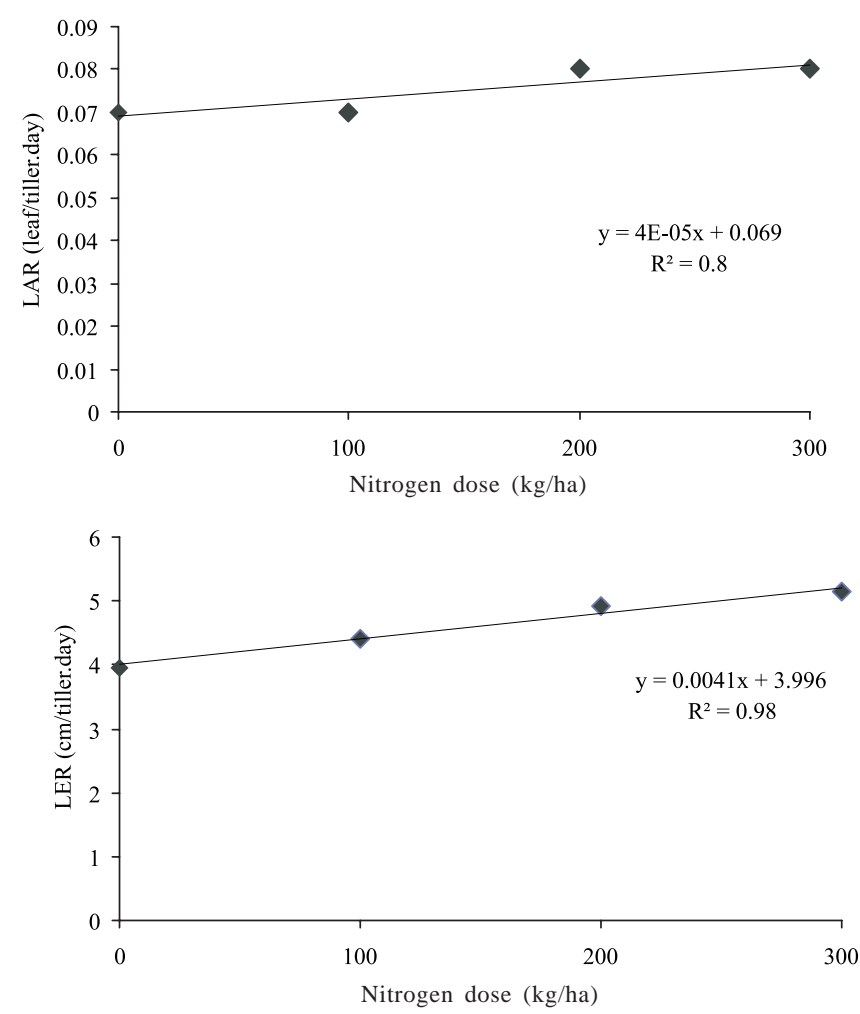

Figure 2 - Leaf appearance rate (LAR) and leaf elongation rate (LER) of Tanzania grass fertilized and non-fertilized with nitrogen according to season.
The leaf elongation rate increase using $300 \mathrm{~kg} / \mathrm{ha}$ of $\mathrm{N}$ was $30.78 \%$ higher than in the absence of nitrogen fertilization. Similar results were obtained by Duru \& Ducrocq (2000), evaluating the effect of nitrogen fertilization on leaf elongation rate. Such behavior of leaf elongation rate caused by nitrogen fertilization is related to the higher cell production (Volenec \& Nelson, 1981). In grasses, the leaf elongation is restricted to a zone in the base of the expanding leaf that is protected by the pseudostem (Skinner \& Nelson, 1995).

The values for final leaf length, phyllochron, number of green leaves, leaf lifespan, stem elongation rate and leaf senescence rate of Tanzania grass were analyzed considering the grazing cycle (in days) as covariable (Table 4).

The ability of plants to expand their leaves depends on the elongation rate of intercalary meristem (cell division zones). This elongation zone is an active local with great nutrient demands (Skinner \& Nelson, 1995). According to Gastal \& Nelson (1994), the highest $N$ accumulation occurs in the division zone, thus explaining the positive response of Tanzania grass to nitrogen fertilization. Similar results were reported by Martuscello et al. (2005), studying Xaraés grass (Brachiaria brizantha cv. Xaraés), in which positive effects of $\mathrm{N}$ doses were observed on leaf elongation rate.

The relationship between leaf elongation rate and leaf appearance rate determines the final length of the leaf blade. Therefore, variations of both leaf elongation rate and leaf appearance rate according to management practices (e.g., fertilization and grazing frequency) or climatic fluctuations, might lead to variation in length of leaf blade. The fertilized experimental units with higher $\mathrm{N}$ doses were grazed more frequently, which caused the reduction in the length of leaf crown, probably as a consequence of a shortened phase of cell proliferation. A similar final leaf length was also reported by Duru \& Ducrocq (2000). According to Lemaire \& Chapman (1996), the length of the leaf blade is a changeable trait that responds to grazing intensity, representing a morphological adaptive strategy of plants to evade grazing.

No differences in length of the leaf blade were observed in relation to season, which exhibited an inverse behavior to leaf elongation rate, i.e., length of the leaf blade presented no significant response to the $\mathrm{N}$ doses tested. During the spring and summer, the highest leaf elongation rate values observed at 200 and $300 \mathrm{~kg} / \mathrm{ha}$ of $\mathrm{N}$ had no effects on length of leaf blade increases.

Values of phyllochron, leaf lifespan, number of green leaves and leaf senescence rate were not affected by the studied treatments or season (spring and summer periods).

Based on the numerical results (Table 4), it can be noticed that, in the lack of nitrogen fertilization, plants 
retained their live leaves for longer periods instead of expanding new leaves. Thus, the decreased leaf lifespan results observed with high $\mathrm{N}$ doses might be explained by the higher tissue renovation in nitrogen-fertilized plants. The leaf lifespan estimate ranged from 66.5 days in plants without nitrogen fertilization to 62.1 days for plants with application of $300 \mathrm{~kg} / \mathrm{ha}$ of N. Mazzanti et al. (1994) pointed out that, in general, leaf lifespan decreases once the leaf elongation rate is higher and the final leaf size increases as nitrogen becomes more available.

Santos et al. (2004) reported no interaction effects between grazing and evaluation periods in leaf senescence rate, describing a higher value, $0.74 \mathrm{~cm} /$ tiller.day, for 28 resting days than that reported in this study $(0.31 \mathrm{~cm} /$ tiller.day). Barbosa et al. (1996) also observed no increased number of senescent leaves in Mombaça grass during 35 days of growth in the summer and 49 days in the fall. Although slightly lower, the result of the present study, of $0.31 \mathrm{~cm} /$ tiller.day, corroborates the data obtained by these authors, which can be related to differences in growth period.

Stem elongation rate during summer was higher than in the spring (Table 4). However, in the spring, stem elongation rate was similar betweem either fertilized or non-fertilized treatments. In the summer, the application of $100 \mathrm{~kg} / \mathrm{ha}$ of $\mathrm{N}$ resulted in higher stem elongation rate in relation to other treatments. By using $100 \mathrm{~kg} / \mathrm{ha}$ of $\mathrm{N}$, the grazing interval was higher, 35 days on average, when compared with 27 to 28 days, on average, observed with 200 to $300 \mathrm{~kg} / \mathrm{ha}$ of $\mathrm{N}$. These data show that nitrogen fertilization associated with shorter grazing intervals is an important tool to control the development of stems, and consequently, the sward structure.

Less intense management (longer grazing periods) possibly determined a higher decapitation of apical meristem, thereby interrupting the apex dormant state and then leading to increased basal and lateral tillering in treatments with $100 \mathrm{~kg} / \mathrm{ha}$ of $\mathrm{N}$.

Table 4 - Mean values of final leaf length (FLL), phyllochron, number of green leaves (NGL), leaf lifespan (LLS), stem elongation rate (SER) and leaf senescence rate (LSR) of Tanzania grass fertilized and non-fertilized with nitrogen in each season

\begin{tabular}{|c|c|c|c|c|c|c|}
\hline \multirow[t]{2}{*}{ Season } & \multicolumn{4}{|c|}{ Treatments } & \multirow[t]{2}{*}{ Mean } & \multirow[t]{2}{*}{ SEM } \\
\hline & 0 & 100 & 200 & 300 & & \\
\hline \multicolumn{7}{|c|}{ FLL $(\mathrm{cm})$} \\
\hline Summer & 25.99 & 27.27 & 23.40 & 25.06 & 25.19 & 3.43 \\
\hline Mean & 26.23 & 26.58 & 24.08 & 25.69 & & \\
\hline SEM & 2.02 & 3.12 & 3.68 & 3.32 & & \\
\hline Summer & 14.53 & 14.29 & 14.57 & 14.42 & 14.46 & 3.56 \\
\hline Mean & 14.26 & 14.22 & 13.68 & 13.33 & & \\
\hline MSE & 3.36 & 4.04 & 4.29 & 3.87 & & \\
\hline \multicolumn{7}{|c|}{ NGL } \\
\hline Spring & 4.61 & 5.07 & 5.01 & 4.98 & 4.94 & 0.40 \\
\hline Spring & 64.03 & 72.76 & 63.26 & 60.57 & 65.26 & 19.83 \\
\hline Summer & 69.02 & 68.94 & 68.27 & 63.60 & 67.15 & 11.23 \\
\hline Mean & 66.52 & 71.23 & 65.76 & 62.08 & & \\
\hline SEM & 15.47 & 21.10 & 15.63 & 12.00 & & \\
\hline \multicolumn{7}{|c|}{ SER (cm/tiller.day) } \\
\hline Spring & $0.02 \mathrm{Aa}$ & $0.04 \mathrm{Ba}$ & $0.02 \mathrm{Ba}$ & $0.02 \mathrm{Ba}$ & 0.02 & 0.04 \\
\hline Summer & $0.07 \mathrm{Ab}$ & $0.23 \mathrm{Aa}$ & $0.12 \mathrm{Ab}$ & $0.12 \mathrm{Ab}$ & 0.13 & 0.12 \\
\hline Mean & 0.04 & 0.12 & 0.07 & 0.07 & & \\
\hline SEM & 0.04 & 0.16 & 0.09 & 0.08 & & \\
\hline \multicolumn{7}{|c|}{ LSR (cm/day) } \\
\hline Spring & 0.40 & 0.31 & 0.24 & 0.36 & 0.31 & 0.21 \\
\hline
\end{tabular}

Mean values followed by distinct capital letters within columns and by distinct regular letters within rows differ (P<0.05) according to SNK test.

SEM - standard error of the mean. 
The tiller population density presented a significant interaction with treatments and evaluation periods (Table 5 and Figure 3). The highest tiller population density was observed in the summer for treatments with the highest nitrogen doses (200 and $300 \mathrm{~kg} / \mathrm{ha}$ ). On the other hand, the treatment without nitrogen fertilization had no difference in relation to plots with $100 \mathrm{~kg} / \mathrm{ha}$ of $\mathrm{N}$. These data diverge from Sarmento et al. (2005), in Millenium IPR-86 using zero; 150,300 and $450 \mathrm{~kg} / \mathrm{ha}$ of $\mathrm{N}$, who reported maximum estimated tiller densities of 239, 194 and 138 tillers $/ \mathrm{m}^{2}$ when doses of 275, 295 and $220 \mathrm{~kg} / \mathrm{ha}$ of N were applied, respectively.

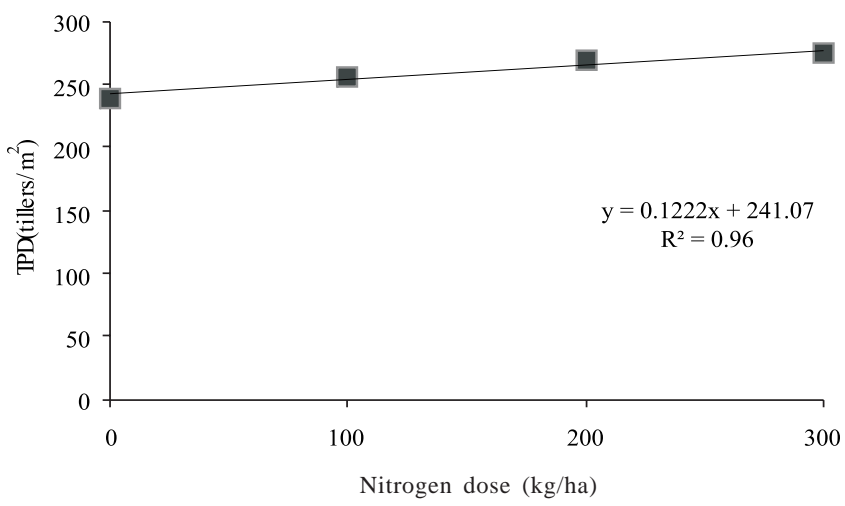

Figure 3 - Tiller population density (TPD, tillers $/ \mathrm{m}^{2}$ ) of Tanzania grass fertilized and non-fertilized with nitrogen according to season.
Garcez Neto et al. (2002), studying Mombaça grass under different nitrogen doses and cutting heights also observed that the nitrogen supplies significantly affected the total number of tillers.

The tiller appearance rate was similar between treatments and selected season periods, varying in 540\% (0.05 to 0.32 tillers/100 tillers.day) for both spring and summer.

Tiller mortality rate presented no differences in relation to $\mathrm{N}$ doses but differed according to season, with a variation of $100 \%$ between the studied seasons.

The highest tiller mortality rate values were observed in the summer, which can be related to environmental conditions added by nitrogen fertilization. Carvalho et al. (2001), evaluating the tillering of Tifton 85 grass (Cynodon dactylon - Grama tifton 85) at different grazing heights, verified a high tiller renovation (increased birth rates) in the summer, and reported that managements practices that assure the high birth rates during the summer are essential to maintain and/or increase the tiller population density through seasons.

In the spring, the tiller age could not be established (beginning of tagging), but the tillers found in the paddocks during this season were usually old, and died faster; in the summer there was a lower tiller survival rate, caused by the higher management intensity and by the renovation of tiller generations.

In the control treatment $(0 \mathrm{~kg} / \mathrm{ha}$ of $\mathrm{N})$, only four grazing cycles were carried out during the experimental period,

Table 5 - Population density of basal tillers (TPD), tiller appearance rate (TAR), tiller mortality rate (TMR), and tiller survival rate (1-TMR) of Tanzania grass fertilized and non-fertilized with nitrogen during spring and summer

\begin{tabular}{|c|c|c|c|c|c|c|}
\hline \multirow[t]{2}{*}{ Season } & \multicolumn{4}{|c|}{ Treatments } & \multirow[t]{2}{*}{ Mean } & \multirow[t]{2}{*}{ SEM } \\
\hline & 0 & 100 & 200 & 300 & & \\
\hline \multicolumn{7}{|c|}{ TPD (tillers $/ \mathrm{m}^{2}$ ) } \\
\hline Spring & $229 \mathrm{Aa}$ & 212Ba & $223 \mathrm{Ba}$ & $224 \mathrm{Ba}$ & 222 & 29.06 \\
\hline Summer & $238 \mathrm{Ac}$ & $256 \mathrm{Abc}$ & $268 \mathrm{Aa}$ & $275 \mathrm{Aa}$ & 259 & 39.53 \\
\hline Mean & 234 & 234 & 246 & 250 & & \\
\hline SEM & 14.00 & 53.93 & 42.33 & 40.62 & & \\
\hline \multicolumn{7}{|c|}{ TAR (tillers/100 tillers.day) } \\
\hline Spring & 0.17 & 0.20 & 0.32 & 0.26 & 0.24 & 0.11 \\
\hline Summer & 0.12 & 0.18 & 0.28 & 0.32 & 0.23 & 0.09 \\
\hline Mean & 0.14 & 0.19 & 0.30 & 0.29 & & \\
\hline SEM & 0.09 & 0.05 & 0.12 & 0.05 & & \\
\hline \multicolumn{7}{|c|}{ TMR (tillers/100 tillers.day) } \\
\hline Spring & 0.04 & 0.03 & 0.03 & 0.05 & $0.04 \mathrm{~B}$ & 0.02 \\
\hline Summer & 0.11 & 0.06 & 0.07 & 0.09 & $0.08 \mathrm{~A}$ & 0.03 \\
\hline Mean & 0.08 & 0.04 & 0.05 & 0.07 & & \\
\hline SEM & 0.04 & 0.02 & 0.03 & 0.03 & & \\
\hline \multicolumn{7}{|c|}{ TSP (1-TMR) } \\
\hline Spring & 0.96 & 0.97 & 0.97 & 0.95 & $0.96 \mathrm{~A}$ & 0.02 \\
\hline Summer & 0.89 & 0.94 & 0.93 & 0.91 & $0.92 \mathrm{~B}$ & 0.03 \\
\hline Mean & 0.92 & 0.96 & 0.95 & 0.93 & & \\
\hline SEM & 0.04 & 0.02 & 0.03 & 0.03 & & \\
\hline
\end{tabular}

Mean values followed by distinct capital letters within columns and by distinct regular letters within rows differ (P<0.05) according to SNK test. SEM - standard error of the mean. 
while the treatment with $100 \mathrm{~kg} / \mathrm{ha}$ of $\mathrm{N}$ yielded five grazing cycles and the treatments with 200 and $300 \mathrm{~kg} / \mathrm{ha}$ of $\mathrm{N}$ resulted in six grazing cycles (Figure 4).

The basal generation (Gen_B) corresponds to the first tiller tagging; it is more numerous during all cycles, and the appearance data could not be determined. In all treatments, the number of tillers per tussock increased, showing that the simple and correct management of pastures can increase the tiller number and consequently the amount of dry matter produced, assuring a higher forage supply for animals.

The fertilization-free treatment yielded the lowest growth (30\%) in tiller population, while growth values of $70 \%, 120 \%$ and $96 \%$ were observed in treatments with 100 , 200 and $300 \mathrm{~kg} / \mathrm{ha}$ of $\mathrm{N}$, respectively.

The tiller population in the basal generation remained stable from February on, in all treatments, which can be explained by the reduction of rainfall (Figure 1) coupled with the nitrogen fertilization (01/24/2008), resulting in decreased grazing intervals within paddocks.

Difante et al. (2008), evaluating the tiller dynamics in marandu grass at different grazing heights and intervals, reported a reduction in both appearance and mortality rates of basal tillers regardless of the analyzed heights and intervals, with the highest tiller appearance rate values observed in December and January, due to the higher tissue renovation being favored by temperature and rainfall increases.

As for the total dry matter production, percentage values of leaf blade (LL \%), stem + crown (SB \%) and dead matter (DM \%) can be noticed, where there was interaction between treatments and season over total dry matter production (Table 6). A higher total dry matter production value was verified in treatments with increased $\mathrm{N}$ amounts, particularly during summer, thus indicating that when the forage matter increases, plants are likely to increase their stems to reach the light, avoiding the shade in inferior levels (Da Silva \& Corsi, 2003).

Barbosa et al. (2007), analyzing the grazing intensity (30 and $50 \mathrm{~cm}$ ) and frequency of light intensity (90, 95 and $100 \%$ in Tanzania grass reported that frequently managed pastures yielded the highest stem percentages, as observed in the present study, once the higher the $\mathrm{N}$ doses and the number of grazing cycles, the higher the forage production.

In the spring, there was a tendency of accumulation of dead matter, since a great amount of senescent material was present at the beginning of the experiment, possibly resulting from the forage accumulation during the winter. The higher
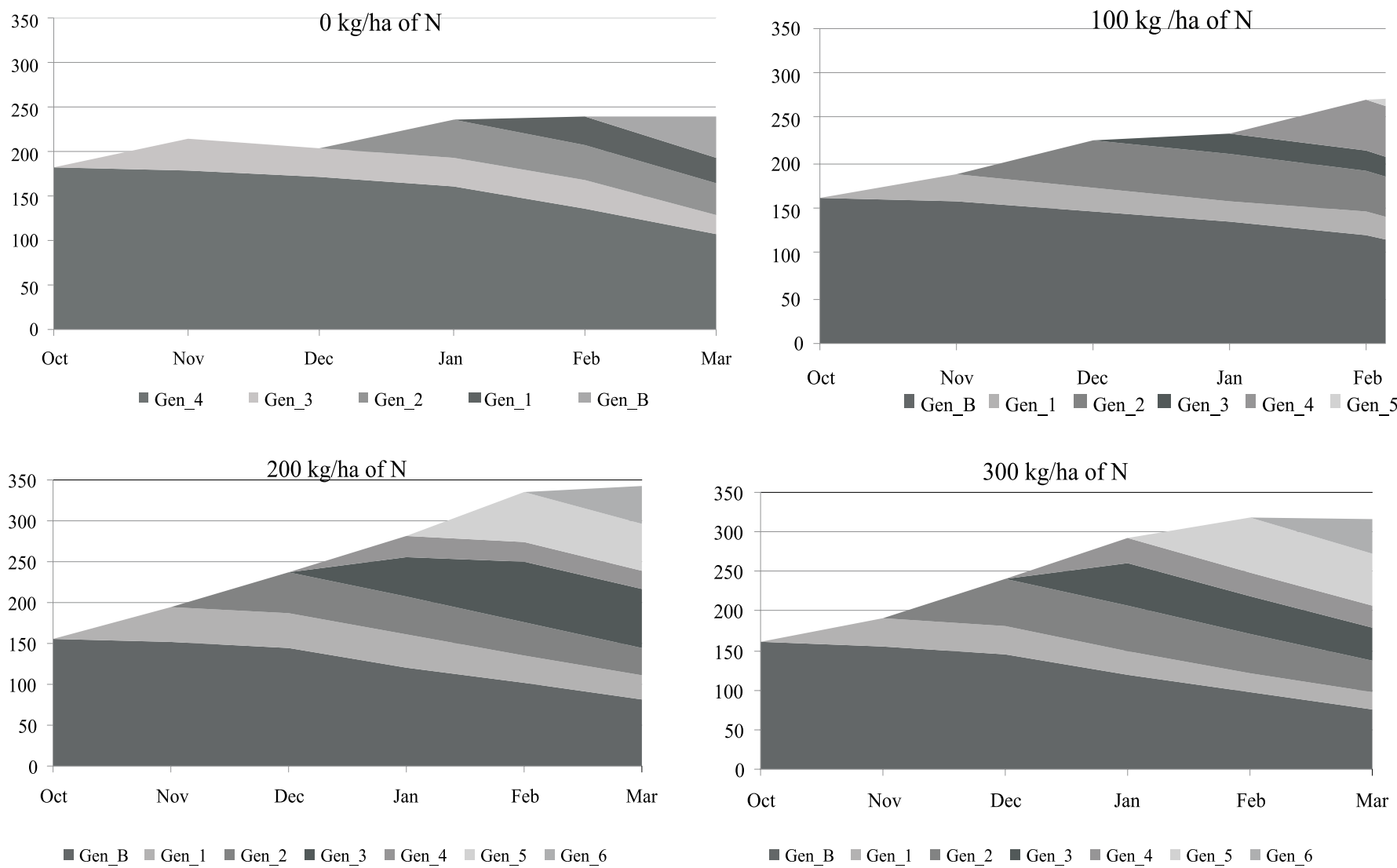

Figure 4 - Population dynamics of total tillers of Tanzania grass fertilized and non-fertilized with nitrogen according to season. 
Table 6 - Total dry matter production, percentage values of leaf blade, stem + crown and dead material of Tanzania grass fertilized and non-fertilized with nitrogen according to season

\begin{tabular}{|c|c|c|c|c|}
\hline \multirow[t]{2}{*}{ Season } & \multicolumn{4}{|c|}{$\mathrm{N}$ dose (kg/ha) } \\
\hline & 0 & 100 & 200 & 300 \\
\hline & \multicolumn{4}{|c|}{ Dry total matter production (t/ha) } \\
\hline \multirow[t]{2}{*}{ Summer } & $4.48(0.48) \mathrm{Ac}$ & $6.55(1.00) \mathrm{Ab}$ & $8.53(1.08) \mathrm{Aa}$ & $8.22(0.44) \mathrm{Aa}$ \\
\hline & \multicolumn{4}{|c|}{ Percentage of leaf blade } \\
\hline Spring & 88.17 (5.40)A & 90.33 (3.05)A & 92.06 (1.34)A & 93.59 (3.73)A \\
\hline Summer & \multicolumn{4}{|c|}{ Percentage of stems + crown } \\
\hline Spring & $2.04(0.67) \mathrm{B}$ & $2.00(1.32) \mathrm{B}$ & 1.95 (0.91)B & $2.17(0.70) \mathrm{B}$ \\
\hline \multirow[t]{2}{*}{ Summer } & 7.99 (3.15)A & 7.57 (0.99)A & $9.52(3.43) \mathrm{A}$ & $9.77(1.11) \mathrm{A}$ \\
\hline & \multicolumn{4}{|c|}{ Percentage of dead matter } \\
\hline Spring & 9.78 (5.55)A & 7.66 (2.85)A & 5.99 (1.50)A & $4.24(3.04) \mathrm{A}$ \\
\hline Summer & $3.34(2.40) \mathrm{B}$ & 1.52 (0.11)B & $4.48(2.08) \mathrm{A}$ & 4.42 (4.59)A \\
\hline
\end{tabular}

Mean values followed by distinct capital letters within columns and by distinct regular letters within rows differ $(\mathrm{P}<0.05)$ according to SNK test. Values in parentheses refer to standard error of the mean.

tiller mortality rate observed in summer might be related to the management performed in each treatment, in which the animals were allowed to graze when plants were 70 -cm high until they reached $30 \mathrm{~cm}$ in height. This procedure determined long periods without management during fall and winter, which caused the forage aging.

The stability index of Tanzania grass remained higher than 1.0 during the entire experimental period. However, this value decreased as the experimental period increased, which might represent a response to season and the beginning of the grass reproductive period, thus modifying the relationship between the appearance and mortality rates of tillers, resulting in higher mortality rates as the seasons passed (Figure 5).

The treatments with 200 and $300 \mathrm{~kg} / \mathrm{ha}$ of $\mathrm{N}$ presented values higher than 1.0 , indicating increased birth rates of

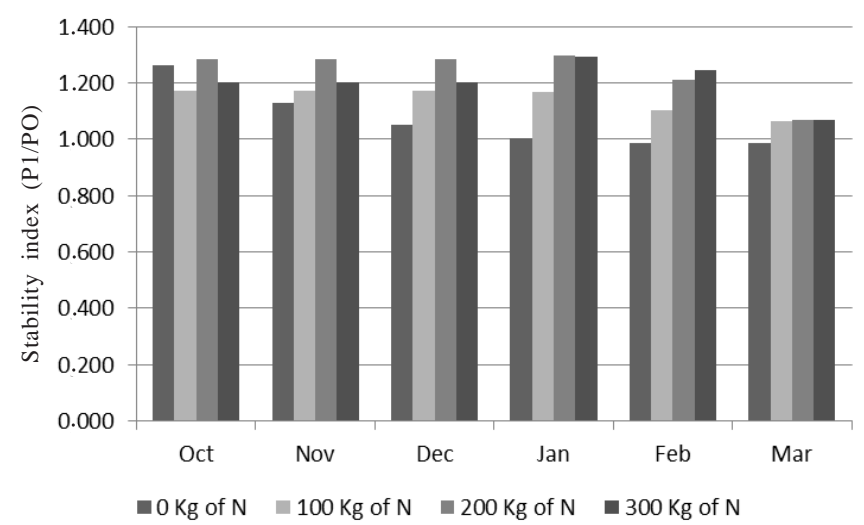

Figure 5 - Stability index of tiller population of Tanzania grass fertilized and non-fertilized with nitrogen according to season. tiller without effects on mortality rates. The stability index started decreasing from December on, mainly in the control treatment, because of weather conditions and reduction of rainfall (Figure 1), leading to the decreased appearance of new tillers, which shows that mortality is higher than birth rate.

The fertilization-free treatment $(0 \mathrm{~kg} / \mathrm{ha}$ of $\mathrm{N})$ had a tendency to stability values below 1.0 by the end of the experimental period, probably due to grazing intervals and the longer resting period required to reach the proper height for grazing, thus causing a higher mortality of tillers. This tendency can also be related to nitrogen deficiencies, an essential element to the appearance of new tillers.

\section{Conclusions}

Fertilization with nitrogen positively affects leaf appearance and elongation rates, as well as the number of live leaves in Tanzania grass during the spring and the summer, thus contributing to a higher production of forage matter. In the spring, the conditions further an increased tiller appearance rate, while the nitrogen leads to a linear growth of tiller population density in summer. The tiller generation remains unchanged by nitrogen fertilization during seasons of pasture growth. However, the population stability of tillers in Tanzania grass is lower when nitrogen fertilization is absent.

\section{References}

BAHMANI, I.; THOM, E.R.; MATTHEW, C. et al. Tiller dynamics of perennial ryegrass cultivars derived from different New Zealand ecotypes: effects of cultivars, season, nitrogen fertilizer, 
and irrigation. Australian Journal of Agricultural Research, v.54, n.8, p.803-817, 2003.

BARBOSA, M.A.A.F.; DAMASCENO, J.C.; CECATO, U. et al. Dinâmica do aparecimento, expansão e senescência de folhas em diferentes cultivares de Panicum maximum Jacq. In: REUNIÃO ANNUAL DA SOCIEDADE BRASILEIRA DE ZOOTECNIA, 43., 1996, Fortaleza. Anais... Fortaleza: SBZ, 1996. p.101-103.

BARBOSA, R.A.; NASCIMENTO JÚNIOR, D.; EUCLIDES, V.P.B. et al. Capim-Tanzânia submetido a combinações entre intensidade e freqüência de pastejo. Pesquisa Agropecuária Brasileira, v.42, n.3, 329-340, 2007.

BUXTON, D.R.; FALES, S.L. Plant environment and quality. In: FAHEY JUNIOR, G.C. (Ed.) Forage quality, evaluation and utilization. Lincoln: University of Nebraska, 1994. p.155-199.

CAVAlCANTE, M.A.B.; GOMIDE, J.A.; PEREIRA, O.G. et al. Características morfogênicas e estruturais do relvado de Brachiaria decumbens cv. Basilisk sob pastejo, em diferentes alturas. In: REUNIÃO ANUAL DA SOCIEDADE BRASILEIRA DE ZOOTECNIA, 38., 2002, Recife. Anais... Recife: SBZ, 2002. p.101-103.

CARVALHO, P.C.F.; MARÇAL, G.K.; RIBEIRO FILHO, H.M.N. et al. Pastagens altas podem limitar o consumo dos animais. In: REUNIÃO ANUAL DA SOCIEDADE BRASILEIRA DE ZOOTECNIA, 38., 2001, Piracicaba. Anais... Piracicaba: SBZ, 2001. p.265-268.

CECATO, U.; SANTOS, G.T.; MACHADO, M.A. Avaliação de cultivares do gênero Cynodon com e sem nitrogênio. Acta Scientiarum, v.23, n.4, p.781-788, 2001.

CHAPMAN, D.F.; LEMAIRE, G. Morphogenetic and structural determinants of plant regrowth after defoliation. In: INTERNATIONAL GRASSLAND CONGRESS, 17., 1993, New Zeland. Proceedings... New Zeland: IGC, 1993. p.95-104.

DA SILVA, S.C.; CORSI, M. Manejo do pastejo. In: SIMPÓSIO SOBRE MANEJO DE PASTAGENS, 20., 2003, Piracicaba. Anais... Piracicaba: FEALQ, 2003. p.155-186.

DIFANTE, G.S.; NASCIMENTO JÚNIOR, D.; DA SILVA, S.C. et al. Dinâmica do perfilhamento do capim-marandu cultivado em duas alturas e três intervalos de corte. Revista Brasileira de Zootecnia, v.37, n.2, p.189-196, 2008.

DURU, M.; DUCROCQ, H. Growth and senescence of the successive Grass leave on a tiller. Ontogenic development and effect of the temperature. Annals of Botany, v.85, p.635-643, 2000.

EMPRESA BRASILEIRA DE PESQUISA AGROPECUÁRIA EMBRAPA. Sistema brasileiro de classificação de solos. Rio de Janeiro: Embrapa Solos, 1999. 171p.

GARCEZ NETO, A.F.; NASCIMENTO JÚNIOR, D.; REGAZZI, A.J. et al. Avaliação das características morfogênicas do Panicum maximum cv. Mombaça em resposta à adubação nitrogenada e alturas de corte. In: REUNIÃO ANUAL DA SOCIEDADE
BRASILEIRA DE ZOOTECNIA, 39., 2002, Recife. Anais... Recife: SBZ, 2002. p.39-40.

GASTAL, F.; NELSON, C.J. Nitrogen use within the growing leaf blade of tall fescue. Plant Physiology, v.105, p.191-197, 1994.

LEMAIRE, E.; CHAPMAN, D. Tissue flows in grazed plant communities. In: HODGSON, I.; ILLIUS, A.W. (Eds.) The ecology and management of grazing systems. Wallingford: $\mathrm{CAB}$ International, 1996. p.3-36.

MARTUSCELLO, J.A.; FONSECA, D.M.; NASCIMENTO JÚNIOR, D. et al. Características morfogênicas e estruturais do capim-Xaraés submetido à adubação nitrogenada e desfolhação. Revista Brasileira de Zootecnia, v.34, n.5, p.1475-1485, 2005.

MAZZANTI, A.; LEMAIRE, G.; GASTAL, F. The effect of nitrogen fertilization upon the herbage production tall fescue swards continuously grazed with sheep. 1. Herbage growth dynamics. Grass and Forage Science, v.49, p.11-120, 1994.

PEARSE, P.J.; WILMAN, D. Effects of applied nitrogen on grass leaf initiation, development and deaf in field swards. Journal of Agricultural Science, v.103, p.405-413, 1984.

SANTOS, P.M.; BALSALOBRE, M.A.A.; CORSI, M. Características morfogenéticas e taxa de acúmulo de forragem do capimmombaça submetido a três intervalos de pastejo. Revista Brasileira de Zootecnia, v.33, p.843-851, 2004.

SANTOS, P.M.; CORSI, M.; BALSALOBRE, M.A.A. Efeito da frequência de pastejo e da época do ano sobre a produção e a qualidade em Panicum maximum cvs. Tanzânia e Mombaça. Revista Brasileira de Zootecnia, v.28, n.2, p.244-249, 1999.

SARMENTO, P.; RODRIGUES, L.R.A.; LUGÃO, S.M.B. et al. Respostas agronômicas e morfológicas de Panicum maximum Jacq. cv. IPR-86 Milênio, sob pastejo, à adubação nitrogenada. Boletim da Indústria Animal, v.62, p.333-346, 2005.

SKINNER, R.H.; NELSON, C.J. Elongation of the grass leaf and its relationship to the phyllochron. Crop Science, v.35, n.1, p.4-10, 1995.

VOLENEC, J.J.; NELSON, C.J. Cell dynamics in leaf meristems of contrasting tall fescue genotypes. Crop Science, v.21, p.381-385, 1981.

UEBELE, M.C. Padrões demográficos de perfilhamento e produção de forragem em pastos de capim-Mombaça submetidos a regimes de lotação intermitente. 2002. $76 \mathrm{f}$. Dissertação (Mestrado em Ciência Animal e Pastagem) - Escola Superior de Agricultura Luiz de Queiroz, Piracicaba.

WENDLING, I.J.; ALENCAR, C.A.B.; TEIXEIRA, S.R. et al. Produção de leite de vacas mestiças holandês $\mathrm{x}$ zebu, em pastagem de capim-elefante (cv. Pioneiro) submetido a dois períodos de descanso. In: REUNIÃO ANUAL DA SOCIEDADE BRASILEIRA DE ZOOTECNIA, 41., 2004, Campo Grande. Anais... Campo Grande: SBZ, 2004. (CD-ROM).

WERnER, J.C.; PAULINO, V.T.; CANTARELLA, H. et al. Forrageiras. In: Recomendações de adubação e calagem para o Estado de São Paulo. 2.ed. Campinas: Instituto Agronômico e Fundação IAC, 1996. p.263-273. (Boletim Técnico, 100). 